\title{
Proteomic Analysis of the GacA Response Regulator in Pseudomonas chlororaphis 06
}

\author{
*Corresponding author \\ Tel: +82-62-530-2071 \\ Fax: +82-62-530-2079 \\ E-mail: yckimyc@jnu.ac.kr \\ ORCID \\ https://orcid.org/0000-0002-7661-7600
}

Received June 3, 2018

Revised June 6, 2018

Accepted June 22, 2018

\author{
Anne J. Anderson ${ }^{1}$ and Young Cheol Kim $\mathbb{1}^{2 *}$ \\ ${ }^{1}$ Department of Biological Engineering, Utah State University, Logan, UT 84322-4105, USA \\ ${ }^{2}$ Department of Applied Biology, Chonnam National University, Gwangju 61186, Korea
}

\begin{abstract}
The GacS/GacA system in the root colonizer Pseudomonas chlororaphis $\mathrm{O} 6$ is a key regulatory system of many traits relevant to the plant probiotic nature of this bacterium. The work in this paper elucidates proteins using proteomics approach in P. chlororaphis $\mathrm{O} 6$ under the control of the cytoplasmic regulatory protein, GacA. A gacA mutant of $P$. chlororaphis $\mathrm{O} 6$ showed loss in production of phenazines, acyl homoserine lactones, hydrogen cyanide, and protease, changes that were associated with reduced in vitro antifungal activity against plant fungal pathogens. Production of iron-chelating siderophore was significantly enhanced in the gacA mutant, also paralleling changes in a gacS mutant. However, proteomic analysis revealed proteins (13 downregulated and 7 upregulated proteins in the mutant compared to parental strain) under GacA control that were not apparent by a proteomic study of a gacS mutant. The putative identity of the downregulated proteins suggested that a gacA mutant would have altered transport potentials. Notable would be a predicted loss of type-VI secretion and PEP-dependent transport. Study of mutants of these GacA-regulated proteins will indicate further the features required for probiotic potential in this rhizobacterium.
\end{abstract}

Keywords: GacA response regulator, Proteomic analysis, Type 6 secretion system, Siderophore
Fluorescent pseduomonads have been studied and developed as biocontrol agents promoting plant health (Kim and Anderson, 2018; Kim et al., 2011). Biological control-active Pseudomonas strains possess many beneficial traits such that they can be considered as examples of plant probiotics (Kim and Anderson, 2018). Recent comparative genomic analysis of ten pseudomonads strains connects their biocontrol potential in part to the production of an array of metabolites active across kingdoms (Loper et al., 2012). The root colonizer, Pseudomonas chlororaphis O6, produces several compounds with antifungal, nematocidal and insecticidal activities, as well as metabolites influencing plant growth that include indole acetic acid and the volatile, 2R,3R-butanediol (Anderson

Research in Plant Disease

pISSN 1598-2262, elSSN 2233-9191

www.online-rpd.org and Kim, 2018; Kim and Anderson, 2018).

The production of many of these biocontrol products is regulated by a two-component global regulatory system. This system is composed of a membrane-bound sensor kinase, GacS, that under environmental stimulus activates the cytoplasmic regulator, GacA (Heeb and Haas, 2001). Transcriptome analyses of gacS or gacA mutants find $10 \%$ of the genes in $P$. fluorescens Pf- 5 are under control of the GacS/GacA regulon (Hassan et al., 2010). Findings with $P$. chlororaphis isolates and other pseudomonads reveal that Gac-regulated traits differ between strains (Li et al., 2015). In P. chlororaphis G5, swimming and indole acetic acid production were decreased, but there was increased biofilm in biofilm formation and survival under oxidative stresses in gacS mutant (Li et al., 2015). In contrast, for P. chlororaphis $\mathrm{O} 6$ the gacS mutation increases swimming and swarming, and indole acetic acid formation (Anderson et al., 2017; Kang et 
al., 2006; Kim et al., 2014b; Kim et al., 2014c; Oh et al., 2013a). Our recent phenotype analysis of the gacS mutant of $P$. chlororaphis $\mathrm{O} 6$ reveals the importance of Gac regulation of polyamine production as part of the regulatory cascade involved in expression of biocontrol-related traits (Park et al., 2018).

Proteomic analysis of mutants defective in the environmental sensor, GacS, or the stress-related sigma factor, RpoS, reveals novel functional proteins that are related to biocontrol (Kim et al., 2014a; Oh et al., 2013b). These include enzymes that function in relief of oxidative stress and in the synthesis of antibiotics. In this study, we constructed a $P$. chlororaphis $\mathrm{O} 6$ mutant defective in gacA to augment our knowledge of the array of beneficial genes controlled by the Gac system. Phenotypic changes in the mutant were examined and proteins markedly changed by elimination of GacA function were identified by a proteomic approach.

Microbial strains and growth conditions. Bacteria were stored at $-80^{\circ} \mathrm{C}$ in $25 \%$ glycerol. The $P$. chlororaphis $\mathrm{O} 6$ parental and mutant strains were grown at $28^{\circ} \mathrm{C}$ with shaking at 200 rpm in King's medium B broth with supplemented with appropriate antibiotics. Cultures of Escherichia coli DH5a were grown at $37^{\circ} \mathrm{C}$ on Luria-Bertani (LB) broth. Antibiotics, streptomycin $(50 \mu \mathrm{g} / \mathrm{ml})$, kanamycin $(50 \mu \mathrm{g} / \mathrm{ml})$, and tetracycline $(25 \mu \mathrm{g} / \mathrm{ml})$ were added where appropriate. To examine in vitro antagonism of growth of fungal pathogens, the wilt pathogen of tomato Fusarium oxysporum (KACC 44452) and the cause of tomato gray mold, Botrytis cinerea (KACC 40574), obtained from the Korean Agricultural Culture Collection (KACC, National Agrobiodiversity Center, Wanju, South Korea), were selected as test targets. The fungal isolates were grown on potato dextrose agar (PDA; Difco Inc., Detroit, MI, USA).

Construction of $\boldsymbol{P}$. chlororaphis $\mathrm{O6}$ gacA mutant. General DNA manipulations, including gene cloning and plasmid isolation were performed using standard protocols (Russell and Sambrook, 2001). All restriction enzymes and modified enzymes were purchased from FastDigest, Thermo Scientific Korea Ltd. (Seoul, Korea). Specific primer set with EcoR1 recognition site at $5^{\prime}$-end was designed to amplify the full gacA gene, the forward primer, 5'-CGGAATTCCTTAAGCTTGCTGAAGCGCC - 3 ' uvrC gene encoded the excinuclease $C$ unit (PchlO6_3798) and the reverse primer, 5'-CGGAATTCCCGTCAGTTATCGGGCCTTGT-3' encoded the hypothetical gene

\section{3 kb PCR product}

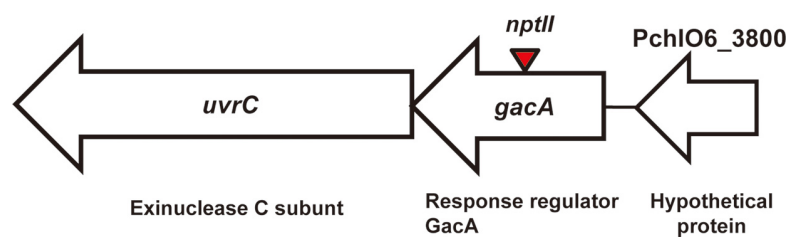

Fig. 1. Gene arrangement of the amplified $2.3 \mathrm{~kb}$ PCR product from Pseudomonas chlororaphis $\mathrm{O6}$ genomic DNA with the specific primer set to amplify the intact gacA gene sequence. Arrows indicate the open reading frames and orientation of gacA and adjacent genes. Vertical arrows indicated the insertion site of the Xbal-digested nptll gene encoding kanamycin resistance into Styl site of open reading frame of gacA gene to interrupt the gene.

(PchlO6_3800) in P. chlororaphis O6 genome (Loper et al., 2012). The $2.3 \mathrm{~kb}$ PCR product, containing a partial sequence of $u v r C$, the intact sequence of gacA, and partial sequence of a hypothetical gene (Fig. 1), was digested with EcoRl and cloned into the pUC19 cloning vector. The gacA gene was interrupted by digestion with Styl and insertion of Xbal digested kanamycin resistance gene (nptl) from pRL648 (Elhai and Wolk, 1988). The $3.2 \mathrm{~kb}$ EcoR1 fragment contained the disrupted gacA::nptll was subcloned into EcoRl digested $\mathrm{pC}$ RIl vector (ThermoFisher Scientific, Carlsbad, CA, USA). The mutated gacA gene was digested with $N$ sil and ligated into Pstl-digested pCPP54 marker exchange vector, and transferred into $P$. chlororaphis $\mathrm{O} 6$ through tri-parental mating using pRK2075 as a helper plasmid. The gacA mutant of $P$. chlororaphis $\mathrm{O} 6$ was selected on LB agar (Difco Inc.) supplemented with $5 \%$ sucrose and kanamycin (Miller et al., 1997). To confirm the mutation in gacA, PCR products were amplified from the mutant using gacA specific primers. The PCR product showed an increase of about $1 \mathrm{~kb}$ in product size as anticipated due to insertion of the kanamycin-resistance gene (data not shown). Sequencing revealed the presence of the nptll gene inserted into the gacA gene between the $103^{\text {th }}$ amino acid, threonine, and the $104^{\text {th }}$ amino acid, lysine, from the start amino acid (Fig. 1).

Phenotypic assays related to biocontrol traits. Biocontrol-related phenotypes of the gacA mutant were assayed by following published procedures (Fig. 2). Briefly, production of acyl homoserine lactones (AHSLs) and phenazines were assayed on TLC plates with cell-free ethyl acetate extracts from $P$. chlororaphis $\mathrm{O} 6$ strains grown in LB 


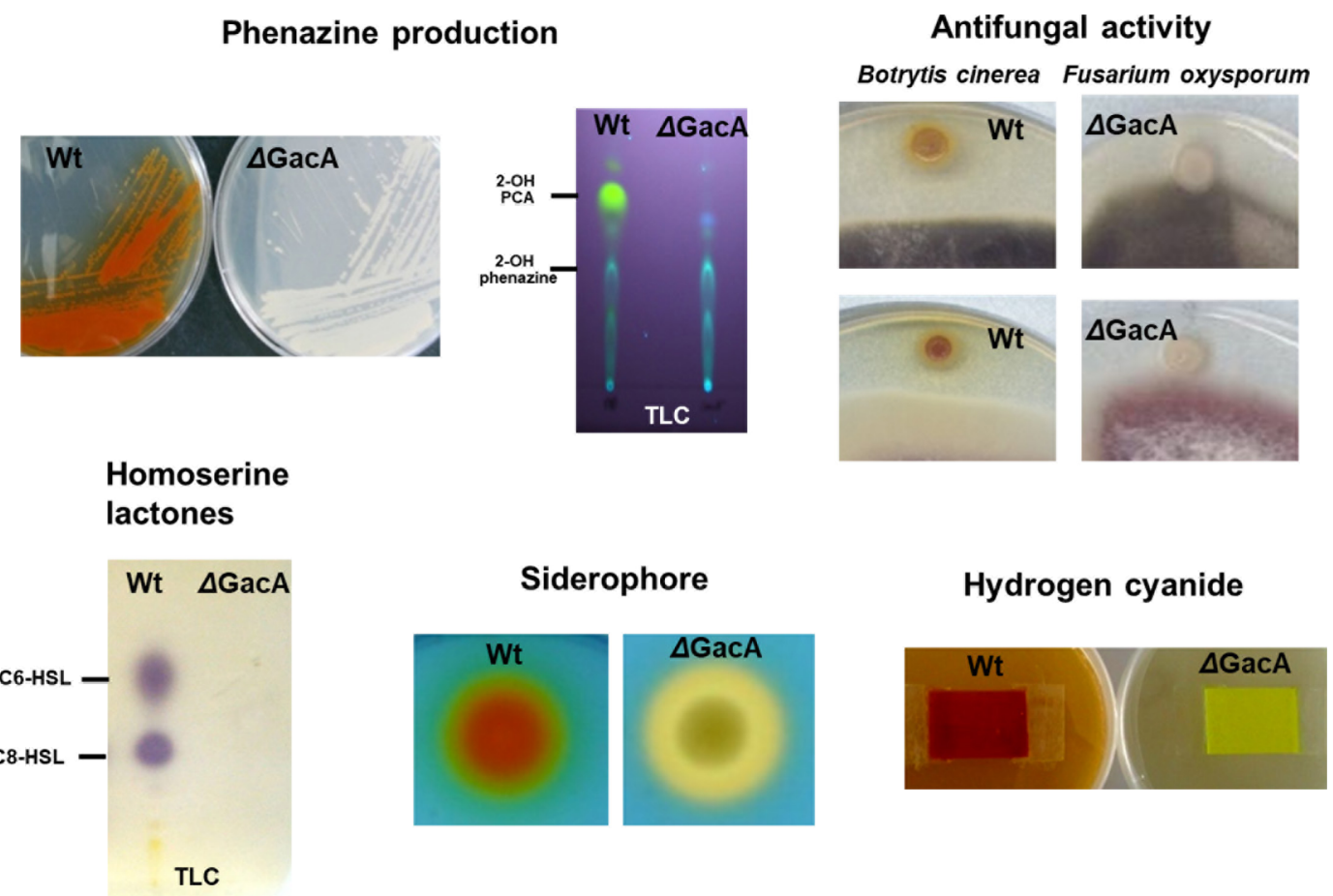

Fig. 2. Phenotypes associated with biocontrol-related traits of the parent strain of $P$. chlororaphis $\mathrm{O} 6$ and its gacA mutant. Phenazine production is denoted in parent strain by orange pigmentation when grown on LB and as fluorescent spots for 2-OH phenazine carboxylic acid (PCA) or 2-OH phenazine when metabolites are separated by TLC. Siderophore production causes a halo where the blue coloration of CAS medium is removed. Acyl homoserine lactones ( 66 and C8 derivatives) are detected after TLC of extracellular metabolites by violet coloration with the $C$. violaceum $\mathrm{CV} 026$ indicator strain. $\mathrm{HCN}$ production causes a red color to develop with Cyantesmo indicator paper. Inhibition of fungal growth is demonstrated on PDA after co-inoculation of bacteria and either of two fungal plant pathogens. Each trait was positive for the parental strain but absent in the gacA mutant. The images are representative of two independent experiments for each bioassay.

broth (Oh et al., 2013a). Fluorescence under UV irradiation was used to detect the phenazines after TLC separation. The Chromobacterium violaceum CV026 bioindicator was used to detect AHSLs on the TLC plate (McClean et al., 1997). Production of hydrogen cyanide was detected on King's medium B agar amended with glycine $(4.5 \mathrm{~g} / \mathrm{l})$ using Cyantesmo paper (Machery-Nagel GmbH \& Co., Duren, Germany) (Kang et al., 2018; Lee et al., 2011). Production of siderophores were detected on chromazol-S agar containing $0.1 \mathrm{mM} \mathrm{FeCl}_{3}$ (Schwyn and Neilands, 1987). For antifungal assessment, the strains were co-cultured for $5 \mathrm{~d}$ with the fungal pathogens $F$. oxysporum and $B$. cinerea on PDA and growth effects measured. All the phenotypic analysis was repeated at least twice.

Production of HCN, phenazines, and AHSLs were significantly decreased by disruption of the gacA gene in P. chlororaphis $\mathrm{O} 6$ (Fig. 2). No phenazines were detected in extracts from the gacA mutant although they were produced by the parental strain (Fig. 2). The gacA mutation in P. chlororaphis G5 also caused the same phenotypic changes (Li et al., 2015).
Mycelial growth of $F$. oxysporum and B. cinerea was inhibited by wild type $P$. chlororaphis $\mathrm{O} 6$ but these fungi overgrew the gacA mutant colonies. Production of an extracellular protease (data not shown) was also reduced by the mutation whereas siderophore was overproduced, as observed with a gacS mutant. These phenotypes were similar to those of the gacS mutant of $P$. chlororaphis O6 (Anderson et al., 2017; Kang et al., 2004, 2007; Kim et al., 2014a, 2014b, 2014c; Oh et al., 2013a; Park et al., 2018; Ryu et al., 2007). These findings indicate that GacA is a functional regulator for these traits, working through regulation by GacS (Kim and Anderson, 2018).

2-D PAGE analysis. To determine some of the proteins that are under GacA in P. chlororaphis O6, soluble peptides were obtained from stationary phase cells and separated by $2 \mathrm{D}$ polyacrylamide gel electrophoresis. Comparisons of the peptide spots generated from extracts of the parental and mutant strains revealed many differences. The 2-D gels were prepared by Genomine (Genomine Inc., Pohang, 
Korea) in Korea (Oh et al., 2013b). Briefly, cell-free soluble protein extracts were obtained by sonication in sample buffer of pelleted cells harvested from $2 \mathrm{~d}$ cultures grown in LB broth. Proteins were first separated by isoelectric focusing at $20^{\circ} \mathrm{C}$ with a pH gradient (4-10) using a Multiphor II electrophoresis unit (Amersham Biosciences, Piscataway, NJ, USA). Separation by size involved loading onto $10-16 \%$ gradient sodium dodecyl sulfate using a Hoefer DALT 2D system (Amersham Biosciences). Peptides in these gels were stained with alkaline silver and their intensities analyzed using PDQuest (BioRad, Hercules, CA, USA) software of the digitized images. Three independent 2-D gel analyses were performed, and the peptides that were significantly up or down-regulated by the gacA mutation were selected, and excised from the gel for matrix assisted laser desorption ionization-time of flight mass spectrometry (MALDI-ToF MS) peptide mass fingerprinting (Kim et al., 2014a; Oh et al., 2013a). The selected protein spots were digested enzymatically in-gel with trypsin (Promega, Madison, WI, USA) for 45 min on ice (Shevchenko et al., 1996) and were desalted on columns. Mass spectra were recorded using an Ettan MALDI-TOF/Pro instrument (Amersham Biosciences, Bucks, UK). Peptide mass fingerprinting was employed to identify proteins of interest. Protein identification was performed using the ProFound search engine, which matches the observed peaks against theoretical peaks in NCBInr and SWISSPROT in nr databases.

For Q-TOF analysis, the remaining trypsin-digested peptides were eluted with $1.5 \mu$ of $50 \%$ methanol/49\% water/1\% formic acid into a pre-coated borosilicate nano-electrospray needle (Micromass, Manchester, UK), and the MS/ MS data obtained with a nano-ESI on a Q-TOF2 mass spectrometer (Micromass). The MS/MS spectra were searched against the protein sequences from the NCBI databases using the MASCOT search program (www.matrixscience.com).

Three independent 2-D PAGE analyses showed more than 1,700 protein spots were reproducibly detected in each gel in the extracts from the parental or mutant cells. More than 100 protein spots were differentially expressed in the gacA mutant compared to the patterns from the parental strain (Fig. 3). From the gels, we selected 20 peptides which changed in intensity more than two-fold as illustrated in Fig. 3. Nine peptides were identified by ProFound search (Table 1) and 11 peptides were classified after LC-MSMS analysis (Table 2).

The putative identities of the proteins that were de-

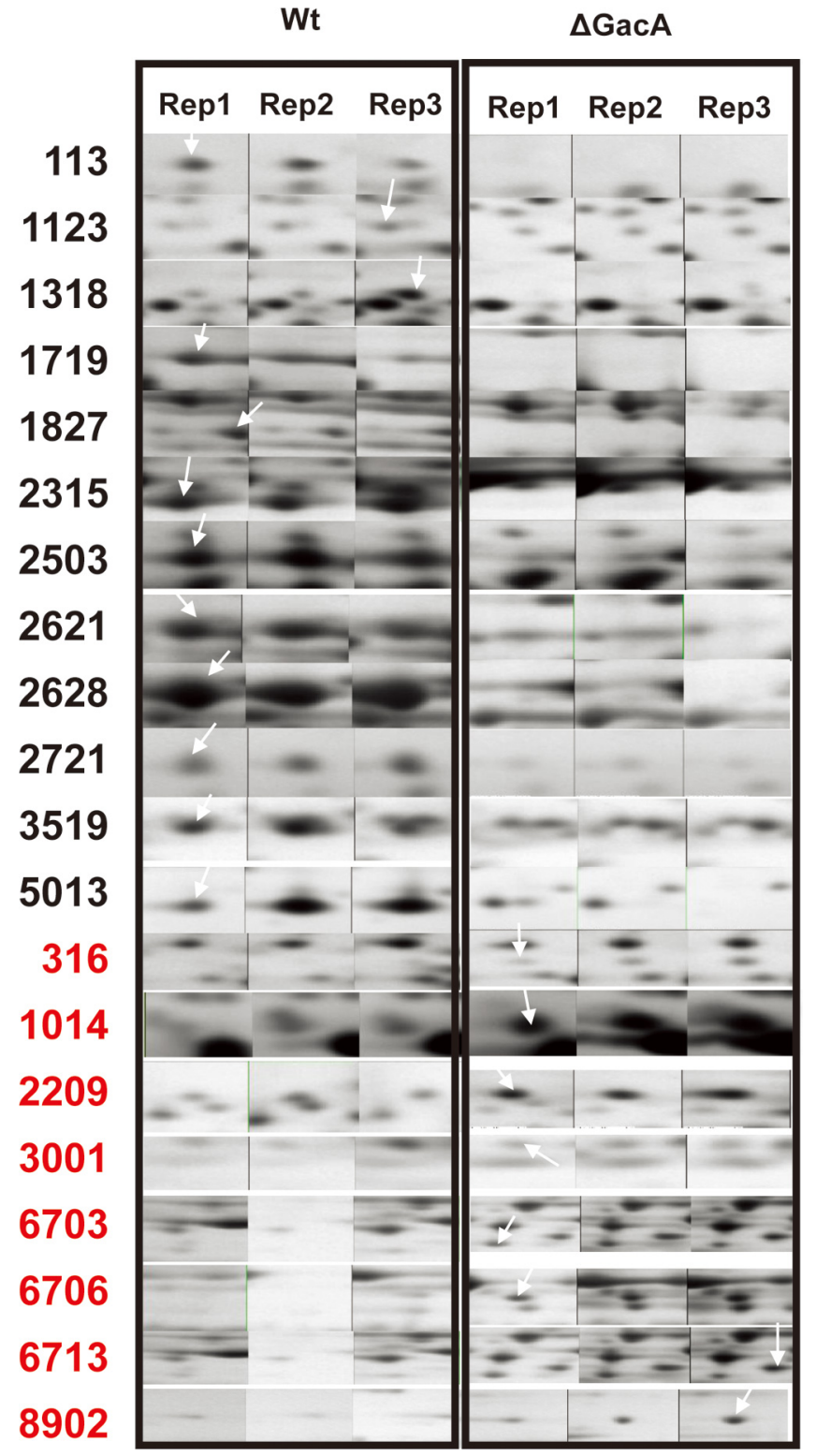

Fig. 3. Intensities of 20 selected peptides differentially expressed in the parental and gacA mutant of Pseudomonas chlororaphis 06. Peptides were detected after two-dimensional polyacrylamide gel electrophoresis. The figures show the peptide intensities for each of three independent analyses. The peptides are denoted by arrows and their putative identities are shown in Tables 2 and 3. The peptides labelled in red increased in the mutant whereas those in black were decreased in intensity by the gacA mutation.

creased in intensity with the gacA mutation indicate that the transport properties of the bacterial cell are altered in multifunctional ways. GacA is required for production of proteins concerned with a type-VI secretion system, with a phosphoenolpyruvate-protein phosphotransferase (PtsP) involved in sugar import into the cell, with efflux involving 
Table 1. Identification of the differentially expressed protein spots in Pseudomonas chlororaphis $\mathrm{O} 6$ wild type and gacA mutant by ProFound search program with data obtained from MALDI-TOF peptide fingerprinting of in-gel tryptic digested protein spots

\begin{tabular}{|c|c|c|c|c|c|c|c|c|c|}
\hline \multirow{2}{*}{$\begin{array}{c}\text { Spot } \\
\text { number }\end{array}$} & \multicolumn{2}{|c|}{$\begin{array}{l}\text { Observed } \\
\text { migration }^{\mathrm{a}}\end{array}$} & \multicolumn{4}{|c|}{ Identified protein by ProFound Search } & \multicolumn{3}{|c|}{ Fold change } \\
\hline & $\begin{array}{c}\mathrm{Mr} \\
\text { (kDa) }\end{array}$ & pl & Est's $Z^{b}$ & Identified gene and protein in P. chlororapis $\mathrm{O6}$ (locus_tag) ${ }^{c}$ & $\begin{array}{c}\mathrm{Mr} \\
(\mathrm{kDa})\end{array}$ & pl & Mean $^{d}$ & $\mathrm{SE}^{\mathrm{d}}$ & $\begin{array}{c}\text { p- } \\
\text { value }\end{array}$ \\
\hline 113 & 28 & 4.45 & 1.50 & pppA, serine/threonine phosphatase (PchlO6_3739) & 26 & 4.95 & -2.6 & 0.5 & 0.020 \\
\hline 1123 & 27 & 4.74 & 2.26 & phage portal protein, HK97 family (PchlO6_1242) & 45 & 5.84 & $>-100$ & & 0.008 \\
\hline 1827 & 87 & 4.79 & 2.35 & ptsP, phosphoenolpyruvate-protein phosphotransferase (PchlO6_5904) & 84 & 5.44 & $>-100$ & & 0.018 \\
\hline 2503 & 52 & 4.96 & 1.71 & emhC, efflux transporter, outer membrane factor (PchlO6_1402) & 52 & 5.69 & $>-100$ & & 0.025 \\
\hline 2628 & 59 & 5.09 & 2.40 & tssC2, type Vl secretion protein TssC2 (PchlO6_6187) & 56 & 5.24 & $>-100$ & & 0.007 \\
\hline 3519 & 54 & 5.16 & 2.32 & $\operatorname{arc} A$, arginine deiminase (PchlO6_4747) & 47 & 5.49 & $>-100$ & & 0.010 \\
\hline 5013 & 20 & 5.76 & 1.71 & type VI secretion system effector, Hcp1 family (PchlO6_0238) & 19 & 5.63 & $>-100$ & & 0.016 \\
\hline 6713 & 81 & 6.02 & 2.35 & parE, DNA topoisomerase IV, B subunit (PchlO6_0539) & 70 & 5.73 & $>100$ & & 0.005 \\
\hline 8902 & 139 & 7.37 & 2.37 & narG, nitrate reductase, alpha subunit (PchlO6_3628) & 140 & 6.31 & $>100$ & & 0.001 \\
\hline
\end{tabular}

${ }^{\mathrm{a}}$ The $\mathrm{Mr}$ and $\mathrm{pl}$ values were estimated from 2-dimensional gels obtained in three independent experiments.

${ }^{b}$ Estimated Z score by ProFound program. Z scores of 1.281, 1.645, 2.326, and 3.090 mean that the search are in the 90th, 95th, 99th and 99.9th percentiles.

'Annotation from NCBI databases and SWISSPRO-nr using the ProFound program.

${ }^{\mathrm{d}}$ The mean and standard error (SE) of fold change of the selected spot was calculated by comparing spot intensities between wild type and gacA mutant of three independent gels using quantitative image analysis (PDQest 2-D analysis Software).

${ }^{\text {e}}$ Student's t-test.

an outer membrane transport factor (EmhC) and with the protein-export membrane protein (SecD) that functions in protein translocation across the cytoplasmic membrane. A portal protein of the HK97 family also decreased in intensity in the gacA mutant. The significance of these changes to the function of the bacterial cell in the rhizosphere awaits full investigation. Naturally occurring gac ${ }^{+}$and gac pseudomonad strains are found in rhizospheres and soil (Seaton et al., 2013). They discuss that both contribute functions that are mutually valuable and suggest that the impact of a functional Gac system would vary with the complexity of the environment (Seaton et al., 2013). Indeed Natsch et al. (1994) found that although a gacA mutant of $P$. fluorescens colonized plant roots, it was less persistent whereas neither colonization nor persistence were affected in the $P$. fluorescens isolate used in the studies of Seaton et al. (2013).

In P. aeruginosa, loss of proteins of the type $\mathrm{Vl}$, TssC1, TssC2, and Hcp1, was observed in the gacA mutant. Additionally the detected decrease in serine/threonine phosphatase (PppA) may lead to altered post translational regulation of type $\mathrm{VI}$ secretion (Chen et al., 2015). Type-VI secretion appears to be multifunctional (Records, 2011). In plant beneficial pseudomonads it is important in biofilm formation as well as in interbacterial competition (Bernal et al., 2018). For instance, tssC mutants in P. fluorescens did not form a biofilm and caused inhibition of biofilm formation of prey target cells in interbacterial competition (Gallique et al., 2017). A T6SS is required for control of the plant bacterial pathogen, Xanthomonas campestris by $P$. putida (Bernal et al., 2017). Similarly a type-VI secretion mechanism is involved in release of toxic effectors, Hcp1 and Hcp2, by P. fluorescens to challenge the soft rot pathogen, Pectobacterium carotovorum (Decoin et al., 2014). Our findings that formation of the type-VI secretion system is dependent on GacA agreed with earlier observations for the gacA mutant of $P$. fluorescens Pf5 (Hassan et al., 2010). $\mathrm{Gac}$ regulation of type $\mathrm{VI}$ secretion also is evident in the bean pathogen, Pseudomonas syringae (Records and Gross, 2010).

There was strong down regulation of a variety of proteins involved in general metabolism in the gacA mutant. Changes involved arginine deiminase (ArCA) required for producing citrulline in the urea cycle, a lipase active in lipid catabolism and an oxidoreductase, zinc-binding dehydrogenase catalyzing the oxidation of alcohols. A putative ATP-dependent helicase involved DNA replication could affect cell division. Transcripts of an oxidoreductase, zinc-binding dehydrogenase, and lipase also were reduced in the gacA mutant of P. fluorescens (Hassan et al., 2010). These findings exemplify similarities in GacA regulation between pseudomonads. 
Table 2. Identification of the protein spots on 2-dimensional analysis regulated by GacA from Pseudomonas chlororaphis 06

\begin{tabular}{|c|c|c|c|c|c|c|c|c|c|}
\hline \multirow[b]{2}{*}{$\begin{array}{c}\text { Spot } \\
\text { number }\end{array}$} & \multicolumn{3}{|r|}{ Observed migration $^{\text {a }}$} & \multicolumn{3}{|l|}{ Identified protein } & \multicolumn{3}{|c|}{ Fold change } \\
\hline & $\begin{array}{c}\mathrm{Mr} \\
(\mathrm{kDa})\end{array}$ & pl & $\begin{array}{l}\text { Identified protein in P. chlororaphis } 06 \\
\text { (locus_tag) }\end{array}$ & Ion Score or Matching sequence ${ }^{d}$ & $\begin{array}{c}\text { Mr } \\
(\mathbf{k D a})\end{array}$ & pl & Meanc & $\mathrm{SE}^{\mathrm{c}}$ & $\begin{array}{c}\text { p- } \\
\text { value }^{d}\end{array}$ \\
\hline 1318 & 39 & 4.71 & $\begin{array}{l}\text { oxidoreductase, zinc-binding dehydrogenase } \\
\text { (PchlO6_0868) }\end{array}$ & DYGDYVRNFWGGGERKP & 15 & 6.14 & $>-100$ & & 0.001 \\
\hline 1719 & 72 & 4.82 & $\begin{array}{l}\text { protein-export membrane protein SecD } \\
\text { (PchlO6_5012) }\end{array}$ & $\begin{array}{l}\text { AIYHFFR } \\
\text { NGGAFVNPIVALAR }\end{array}$ & 68 & 5.22 & $>-100$ & & 0.001 \\
\hline 2315 & 41 & 5.13 & lipase, class 3 (PchlO6_3236) & $\begin{array}{l}\text { KISITHAYVVNNSAR } \\
\text { RTSVPASISPGTAIRKK }\end{array}$ & 36 & 5.31 & $>-100$ & & 0.002 \\
\hline 2621 & 67 & 5.11 & type VI secretion protein TssC1 (PchlO6_3748) & $\begin{array}{l}\text { LPYHGHFNR } \\
\text { IFTTPEHPAVSR }\end{array}$ & 55 & 5.37 & $>-100$ & & 0.016 \\
\hline 2721 & 72 & 4.96 & $\begin{array}{l}\text { putative ATP-dependent helicase } \\
\text { (PchlO6_5564) }\end{array}$ & CAALLNCYFPGAR & 158 & 6.05 & $>-100$ & & 0.016 \\
\hline 316 & 39 & 4.57 & $\begin{array}{l}\text { extracellular solute-binding protein } \\
\text { (PchlO6_3412) }\end{array}$ & $\begin{array}{l}\text { R.AVDAEFWVDHGEELEQR.F(80) } \\
\text { R.FNAWAAR.(21) }\end{array}$ & 38 & 5.10 & $>100$ & & 0.025 \\
\hline 1014 & 15 & 4.91 & MaoC-like protein (PchlO6_5497) & $\begin{array}{l}\text { R.INLFAEATGDFQFIHVDPVK.A(87) } \\
\text { K.KPGQWLLK.A(43) } \\
\text { K.MVVNYGLDSVR.F(39) }\end{array}$ & 17 & 5.20 & $>100$ & & 0.018 \\
\hline 2209 & 38 & 5.05 & $\begin{array}{l}\text { TonB-dependent outer membrane receptor } \\
\text { (PchlO6_3670) }\end{array}$ & CAAVSLDLENHFP EGAHDPPFALDER & 86 & 5.57 & 2.8 & 0.6 & 0.021 \\
\hline 3001 & 24 & 5.14 & antioxidant, AhpC/TSA family (PchlO6_4904) & $\begin{array}{l}\text { KAYDVESEGGVAFRG (66) } \\
\text { R.SQIVNDLPLGR.N (32) } \\
\text { R.NVEVIAVSIDSHFTHNAWR.N (14) }\end{array}$ & 22 & 5.18 & $>100$ & & 0.013 \\
\hline 6703 & 80 & 5.89 & $\begin{array}{l}\text { monovalent cation/proton antiporter, MnhAB/ } \\
\text { PhaAB subunit (PchlO6_2634) }\end{array}$ & SSLAKHYWLP & 105 & 9.55 & $>100$ & & 0.014 \\
\hline 6706 & 73 & 5.92 & hypothetical protein (PchlO6_2333) & $\begin{array}{l}\text { ESLLMEADPSSH } \\
\text { KLDGVADSADVENGLSPPG }\end{array}$ & 57 & 6.25 & $>100$ & & 0.021 \\
\hline
\end{tabular}

${ }^{2} \mathrm{The} \mathrm{Mr}$ and pl values were estimated from 2-dimensional gels obtained in three independent experiments. lons score is -10*Log (P), where $\mathrm{P}$ is the probability that the observed match is a random event. Individual ions scores $>49$ indicate identity or extensive homology $(p<0.05)$. Protein scores are derived from ions scores as a non-probabilistic basis for ranking protein hits. Amino acid sequences without ion scores were determined by Q-TOF analysis.

${ }^{\mathrm{b}}$ Annotation from NCBI databases using the MASCOT search program (www.matrixscience.com).

'The mean and standard error (SE) of fold change of the selected spot was calculated by comparing spot intensities between wild type and gacA mutant of three independent gels using quantitative image analysis (PDQest 2-D analysis Software).

${ }^{\mathrm{d}}$ Student's t-test.

In our previous proteomic analysis with a gacS mutant, we identified reduced levels of proteins with major functions in reducing oxidative stress, a catalase/peroxidase (KatG) and glutathione peroxidase. The failure of the gacS mutant to produce the antibiotic, pyrrolnitrin, also correlated with loss of a functional GacS sensor eliminating tryptophan synthesis (TrpE) and tryptophan halogenase (PrnA), catalyzing the first step in synthesis of this antibiotic (Kim et al., 2014a). However, none of these previously identified proteins were identified as being changed with loss of GacA. Reduced expression of genes for the Fe-superoxide dismutase, a catalase and a peroxidase were also evident from transcriptome analysis of the effects of a gacA mutation in P. fluorescens (Hassan et al., 2010) and this difference may reflect variability among isolates.

Expression of eight protein spots was significantly enhanced by loss of the GacA function. These proteins have diverse but little understood functions such as the $B$ subunit of DNA topoisomerase IV, an extracellular solute-binding protein, a MaoC-like protein, a monovalent cation/proton antiporter and an hypothetical protein, as well as proteins with more characterized roles: nitrate reductase, a TonB- 
dependent outer membrane receptor, and an antioxidant of the AhpC/TSA family. The increased expression of nitrate reductase contrasts with the findings in P. fluorescens Pf5 where the expression from a gene involved in the enzyme's structure was decreased in by gacA mutation (Hassan et al., 2010), again illustrating the uniqueness of regulatory pathways between isolates in the pseudomonad genus. Increased expression of nitrate reductase could be related to the need of the cell to use denitrification to supplement altered electron flow possibly due to cell membrane disturbance.

Higher levels of the TonB-dependent outer membrane receptor may be related to the enhanced secretion of siderophore in the gacA mutants of $P$. chlororaphis strains (Liu et al., 2018; Oh et al., 2013b). Several siderophore-related transcripts also increased in the transcriptome analysis of the gacA mutant of P. fluorescens (Hassan et al., 2010). The proteomic analysis of the GacS function in P. chlororaphis O6 showed GacS dependency for production of isozymes of catalase and peroxidase involved in protection against oxidative stress (Kang et al., 2004). In this study, levels of an antioxidant, AhpC/TSA family protein, were significantly increased in the gacA mutant of $P$. chlororaphis O6. Whether this change promotes tolerance of the gacA mutant to oxidative stress requires examination.

In summary, mutational analysis of gacA confirmed the key role of the GacS/GacA global regulator in expression of many traits in $\mathrm{P}$. chlororaphis $\mathrm{O} 6$ involved with biocontrol of microbes. The proteomics analysis confirmed a role of GacA as a key regulator of proteins with varied cellular function, especially in production of a type VI secretion system. These findings indicate that future research into how the Gac regulatory system affects biofilm formation and interactions with other microbes should aid in understanding the probiotic potential for isolates such as $\mathrm{P}$. chlororaphis $\mathrm{O} 6$ to improve plant health.

\section{Conflicts of Interest}

No potential conflict of interest relevant to this article was reported.

\section{Acknowledgements}

This work was supported by the Korea Institute of Planning and Evaluation for Technology in Food, Agriculture, Forestry and Fisheries (IPET) through the Agri-Bio Industry Technology Development Program, funded by the Ministry of Agriculture, Food and Rural Affairs (grant no. 316032-5).

\section{References}

Anderson, A. J. and Kim, Y. C. 2018. Biopesticides produced by plant-probiotic Pseudomonas chlororaphis isolates. Crop Protect. 105: 62-69.

Anderson, A. J., Kang, B. R. and Kim, Y. C. 2017. The Gac/Rsm signaling pathway of a biocontrol bacterium, Pseudomonas chlororaphis O6. Res. Plant Dis. 23: 212-227.

Bernal, P., Allsopp, L. P., Filloux, A. and Llamas, M. A. 2017. The Pseudomonas putida T6SS is a plant warden against phytopathogens. ISMEJ. 11: 972-987.

Bernal, P., Llamas, M. A. and Filloux, A. 2018. Type VI secretion systems in plant-associated bacteria. Environ. Microbiol. 20: 1-15.

Chen, L., Zou, Y., She, P. and Wu, Y. 2015. Composition, function, and regulation of T6SS in Pseudomonas aeruginosa. Microbiol. Res. 172: 19-25.

Decoin, V., Barbey, C., Bergeau, D., Latour, X., Feuilloley, M. G. J., Orange, N. et al. 2014. A type $\mathrm{Vl}$ secretion system is involved in Pseudomonas fluorescens bacterial competition. PLoS One 9: e89411.

Elhai, J. and Wolk, C. P. 1988. A versatile class of positive-selection vectors based on the nonviability of palindrome-containing plasmids that allows cloning into long polylinkers. Gene 68: 119-138.

Gallique, M., Decoin, V., Barbey, C., Rosay, T., Feuilloley, M. G. J., Orange, N. et al. 2017. Contribution of the Pseudomonas fluorescens MFE01 type VI secretion system to biofilm formation. PLoS One 12: e0170770.

Hassan, K. A., Johnson, A., Shaffer, B. T., Ren, Q., Kidarsa, T. A., Elbourne, L. D. H. et al. 2010. Inactivation of the GacA response regulator in Pseudomonas fluorescens Pf-5 has far-reaching transcriptomic consequences. Environ. Microbiol. 12: 899-915.

Heeb, S. and Haas, D. 2001. Regulatory roles of the GacS/GacA two-component system in plant-associated and other gramnegative bacteria. Mol. Plant Mlcrobe Interact. 14: 1351-1363.

Kang, B. R., Anderson, A. J. and Kim, Y. C. 2018. Hydrogen cyanide produced by Pseudomonas chlororaphis $\mathrm{O} 6$ exhibits nematicidal activity against Meloidogyne hapla. Plant Pathol. J. 34: 3543.

Kang, B. R., Cho, B. H., Anderson, A. J. and Kim, Y. C. 2004. The global regulator GacS of a biocontrol bacterium Pseudomonas chlororaphis $\mathrm{O} 6$ regulates transcription from the rpoS gene encoding a stationary-phase sigma factor and affects survival in oxidative stress. Gene 325: 137-143.

Kang, B. R., Han, S. H., Zdor, R. E., Anderson, A. J., Spencer, M., Yang, K. Y. et al. 2007. Inhibition of seed germination and induction of systemic disease resistance by Pseudomonas chlororaphis $\mathrm{O} 6$ 
requires phenazine production regulated by the global regulator, gacS. J. Microbiol. Biotech. 17: 586-593.

Kang, B. R., Yang, K. Y., Cho, B. H., Han, T. H., Kim, I. S., Lee, M. C. et al. 2006. Production of indole-3-acetic acid in the plant-beneficial strain Pseudomonas chlororaphis $\mathrm{O} 6$ is negatively regulated by the global sensor kinase GacS. Curr. Microbiol. 52: 473-476.

Kim, C. H., Kim, Y. H., Anderson, A. J. and Kim, Y. C. 2014a. Proteomic analysis of a global regulator GacS sensor kinase in the rhizobacterium, Pseudomonas chlororaphis O6. Plant Pathol. J. 30: 220-227.

Kim, J. S., Kim, Y. H., Anderson, A. J. and Kim, Y. C. 2014b. The sensor kinase GacS negatively regulates flagellar formation and motility in a biocontrol bacterium, Pseudomonas chlororaphis 06. Plant Pathol. J. 30: 215-219.

Kim, J. S., Kim, Y. H., Park, J. Y., Anderson, A. J. and Kim, Y. C. 2014c. The global regulator GacS regulates biofilm formation in Pseudomonas chlororaphis $\mathrm{O} 6$ differently with carbon source. Can. J. Microbiol. 60: 133-138.

Kim, Y. C. and Anderson, A. J. 2018. Rhizosphere pseudomonads as probiotics improving plant health. Mol. Plant Pathol. DOI: 10.1111/mpp.12693. (In press)

Kim, Y. C., Leveau, J., McSpadden Gardener, B. B., Pierson, E. A., Pierson, L. S., 3rd and Ryu, C. M. 2011. The multifactorial basis for plant health promotion by plant-associated bacteria. Appl. Environ. Microbiol. 77: 1548-1555.

Lee, J. H., Ma, K. C., Ko, S. J., Kang, B. R., Kim, I. S. and Kim, Y. C. 2011. Nematicidal activity of a nonpathogenic biocontrol bacterium, Pseudomonas chlororaphis O6. Curr. Microbiol. 62: 746-751.

Li, J., Yang, Y., Dubern, J. F., Li, H., Halliday, N., Chernin, L., Gao, K. et al. 2015. Regulation of GacA in Pseudomonas chlororaphis strains shows a niche specificity. PLoS One 10: e0137553.

Liu, Y., Wang, Z., Bilal, M., Hu, H., Wang, W., Huang, X. et al. 2018. Enhanced fluorescent siderophore biosynthesis and loss of phenazine-1-carboxamide in phenotypic variant of Pseudomonas chlororaphis HT66. Front. Microbiol. 9: 759.

Loper, J. E., Hassan, K. A., Mavrodi, D. V., Davis, E. W., 2nd, Lim, C. K., Shaffer, B. T. et al. 2012. Comparative genomics of plant-associated Pseudomonas spp.: insights into diversity and inheritance of traits involved in multitrophic interactions. PLoS Genetics 8: e1002784.

McClean, K. H., Winson, M. K., Fish, L., Taylor, A., Chhabra, S. R., Camara, M. et al. 1997. Quorum sensing and Chromobacterium violaceum: exploitation of violacein production and inhibition for the detection of $\mathrm{N}$-acylhomoserine lactones. Microbiology
143: 3703-3711.

Miller, C. D., Kim, Y. C. and Anderson, A. J. 1997. Cloning and mutational analysis of the gene for the stationary-phase inducible catalase (catC) from Pseudomonas putida. J. Bacteriol. 179: 52415245.

Natsch, A., Keel, C., Pfirter, H. A., Haas, D. and Défago, G. 1994. Contribution of the global regulator gene gacA to persistence and dissemination of Pseudomonas fluorescens biocontrol strain $\mathrm{CHAO}$ introduced into soil microcosms. Appl. Environ. Microbiol. 60: 2553-2560.

Oh, S. A., Kim, J. S., Han, S. H., Park, J. Y., Dimkpa, C., Edlund, C. et al. 2013a. The GacS-regulated sigma factor RpoS governs production of several factors involved in biocontrol activity of the rhizobacterium Pseudomonas chlororaphis O6. Can. J. Microbiol. 59: 556-562.

Oh, S. A., Kim, J. S., Park, J. Y., Han, S. H., Dimkpa, C., Anderson, A. J. et al. 2013b. The RpoS sigma factor negatively regulates production of IAA and siderophore in a biocontrol rhizobacterium, Pseudomonas chlororaphis O6. Plant Pathol. J. 29: 323-329.

Park, J. Y., Kang, B. R., Ryu, C. M., Anderson, A. J. and Kim, Y. C. 2018. Polyamine is a critical determinant of Pseudomonas chlororaphis O6 for GacS-dependent bacterial cell growth and biocontrol capacity. Mol. Plant Pathol. 19: 1257-1266.

Records, A. R. 2011. The type VI secretion system: a multipurpose delivery system with a phage-like machinery. Mol. Plant Microbe Interact. 24: 751-757.

Records, A. R. and Gross, D. C. 2010. Sensor kinases RetS and LadS regulate Pseudomonas syringae type $\mathrm{VI}$ secretion and virulence factors. J. Bacteriol. 192: 3584-3596.

Russell, D. W. and Sambrook, J. 2001. Molecular cloning: a laboratory manual. 3rd ed. Cold Spring Harbor Laboratory, Cold Spring Harbor, NY, USA, 999 pp.

Ryu, C. M., Kang, B. R., Han, S. H., Cho, S. M., Kloepper, J. W., Anderson, A. J. et al. 2007. Tobacco cultivars vary in induction of systemic resistance against Cucumber mosaic virus and growth promotion by Pseudomonas chlororaphis $\mathrm{O} 6$ and its gacS mutant. Eur. J. Plant Pathol. 119: 383-390.

Schwyn, B. and Neilands, J. B. 1987. Universal chemical assay for the detection and determination of siderophores. Anal. Biochem. 160: 47-56.

Seaton, S. C., Silby, M. W. and Levy, S. B. 2013. Pleiotropic effects of GacA on Pseudomonas fluorescens Pf0-1 in vitro and in soil. Appl. Environ. Microbiol. 79: 5405-5410. 